\title{
Legal Analysis of the Nature of Cyber Currency in Iran: A Comparison to EU Law
}

\author{
Nima Norouzi* \\ Islamic Azad University, Iran
}

\begin{abstract}
Electronic money as the monetary value stored in an electronic instrument is the last step in the gradual evolution of money, described as the immaterialization and invisibility of money. It is an emerging phenomenon that can perform the functions and duties of money. This study aimed to investigate the legal concept of cyber currency in Iran-Islamic and EU law in a comparative view. This study mainly considered e-money as a payment method and discussed it from different perspectives. In analyzing the legal nature of this phenomenon, it used two different approaches by combining an empirical-analytical method and a comparative study. The first approach was to analyze the nature of electronic money as a type of money. The second was to analyze the nature of electronic money in the light of non-monetary theories and describe it as one of the legal institutions used in business. This study concluded that electronic money would have different legal effects in its legal analysis, depending on who the publisher and acceptor are and how its publication and circulation process is defined and explained. The description of electronic money in the form of non-monetary theories ignored its role as an efficient payment tool in today's advanced business environment.
\end{abstract}

KEYWORDS: Electronic Money, Cyber Currency, Islamic Law.

Copyright $\odot 2021$ by Author(s)

This work is licensed under a Creative Commons Attribution-ShareAlike 4.0 International License. All writings published in this journal are personal views of the authors and do not represent the views of this journal and the author's affiliated institutions.

\section{HOW TO CITE:}

Norouzi, Nima, "Legal Analysis of the Nature of Cyber Currency in Iran: A Comparison to EU Law" (2021) 2:2 Indonesian Journal of Law and Society 165-196, online: <https://doi.org/ 10.19184/ijls.v2i2.26660>.

Submitted: 21/07/2021 Reviewed: 26/08/2021 Revised: 29/09/2021 Accepted: 30/09/2021

\footnotetext{
* Corresponding authors' e-mail: n.nima1376@gmail.com
} 


\section{INTRODUCTION}

The use of electronic money is described as a process of immaterialization and invalidity of money. ${ }^{1}$ This emerging phenomenon, which is technically undergoing its development process and economically gradually opening its place among monetary instruments as a means of payment in retail exchanges, is gradually gaining attention. ${ }^{2}$ Then, the national and regional currencies are regulated, with the European Union leading the way in issuing guidelines on e-money. ${ }^{3}$

There have been rare existing literature that investigated the nature of emoney. Mengjia argued that e-money is not a real currency and it possesses some nature and functions of currency. ${ }^{4}$ To some extent, the circulation is restricted within cyberspace, a measure of relative values and a payment tool. ${ }^{5}$ Another study by Zharova and Lloyd lacked a conceptual framework of the cyber-currency that concerned the use of crypto-currency with specific reference to the situation in Russia. ${ }^{6}$ A variety of such systems exist, like bitcoin, but it is perhaps the best-known example and will be used as synonymous with the concept throughout this article. ${ }^{7}$ Also, Breu studied blockchain technology and its future legal challenges. ${ }^{8}$ Although this study was a turning point in this field, it was case limited, and no conceptual legal

1 Faraz Adam, "Fatawa Analysis of Bitcoin" in Halal Cryptocurrency Management (Palgrave Macmillan, 2019). at 133-147.

2 Habib Farrukh, "Fintech, Digital Currency and the Future of Islamic Finance" in $A$ Critical Analysis of Bitcoin from Islamic Legal Perspective (Palgrave Macmillan, 2021). At 9-29.

3 In the recent period, many countries such as the United States, Australia, Russia, China, Ukraine, Indonesia, and Singapore regulated cyber currency.

4 Mengjia, Y. U. "Analysis of Impact and Nature of Cyber Virtual Currency Based QB." Business Economy 2014 (2014): 16.

5 Ibid.

6 Anna Zharova \& Ian Lloyd, "An examination of the experience of cryptocurrency use in Russia. In search of better practice" (2018) 34:6 Computer Law \& Security Review 1300-1313.

7 Ibid.

8 Stephan Breu, "Are Blockchains and Cybercurrencies Demanding a New Legislative Framework” (2018) 1 Journal Law and Digital Economy. 
analysis in terms of evolutionary, empirical, or analytic methods was implemented. ${ }^{9}$

This study was based on the hypothesis that electronic money for economic functions can perform functions such as legal money or written money, but legally following these rules and regulations on the electronic transfer of funds and the conditions of activity of electronic money publishers. The European Parliament and the Council of Europe have inspired European national systems, first with the adoption of Directive 2000/46/EC and, more recently, with Directive 2009/110/EC. In Iran, so far, no regulations have been enacted on electronic money in a specific sense, and regulations such as the regulations on the use of electronic money services, approved by the Cabinet on 5/5/2005, ${ }^{10}$ regulate its general meaning and electronic transmission. The publisher and acceptor and how the publication and circulation process is defined and explained will have different legal effects.

Two descriptive methods have been used, and the approach of European systems, especially France and the American system, ${ }^{11}$ as a typical model on the one hand, and Islamic law as reflected in the views of jurisprudential thinkers, the other hand, is different. Electronic money is used in the banking literature in both general and specific senses. In a general sense, emoney encompasses all forms of electronic payment. ${ }^{12}$ In its specific sense, polyelectronics is the monetary value stored in an electronic instrument

9 Ibid.

${ }^{10}$ In its specific sense, electronic money differs from the methods of electronic payment or transfer of funds (access products) that enable customers to use electronic means of communication to access traditional payment services. This means using a personal computer and the internet or mobile phones and telephone lines to pay for an electronic bank account and pay by credit or debit card, typically requiring online communication and verification.

11 A Manimuthu et al., "A Literature Review on Bitcoin: Transformation of Crypto Currency Into a Global Phenomenon" (2019) IEEE Engineering Management Review at 28-35.

12 Luqman Nurhisam, "Bitcoin: Islamic law perspective" (2017) 5:2 Qudus International Journal of Islamic Studies. 
issued in exchange for the receipt of funds and accepted as a means of payment ${ }^{13}$ by natural persons or legal entities other than the issuer.

This study aimed to analyze the concept of the cyber currency in the IranIslamic judicial system and compare it with the EU law. ${ }^{14}$ In particular, it reviewed the evolution of the monetary law and then compared principles and theories of this field..$^{15}$ Then, the most unified and aligned theories will be chosen to conceptualize the cyber currency in Iran-Islamic law. ${ }^{16}$ Finally, this evolutionary-analytic study will be compared with the latest legislation of the EU region, mainly French law, due to its compatibility with Islamic law.

This study is structured into three sections. The first section discusses the nature of cyber currency that mainly considers the evolution of money and structurize its legal entity through time. The second section studies the cyber currency using the results of evolutionary studies of the monetary theories. This section conceptualizes the cyber currency in the Iran-Islamic jurisprudence. The third section discusses the payment in cyber currency and its banking deposition.

\section{METHODS}

Given that this study was to analyze the cyber currency in the Iran-Islamic judicial system and compare it with the EU law, the research method in this research was empirical-analytical. The empirical analysis is an evidence-based approach to the study and interpretation of information. It never gives an absolute answer, but only a most likely answer based on probability. The concept in this study was identified using theoretical

13 Electronic money products are sometimes card-based (storing value in a microprocessor chip housed in a plastic card) and sometimes software-based (specialized software installed on PCs).

14 Stjepan Begusic, et al., "Scaling properties of extreme price fluctuations in Bitcoin markets" (2018) 510 Physica A: Statistical Mechanics and its Applications at 400406.

15 Alam Nafis, Lokesh Gupta \& Zameni Abdolhossein, "Cryptocurrency and Islamic Finance" in Fintech and Islamic Finance (Palgrave Macmillan, 2019) at 99-118.

16 Adam, Mufti Faraz \& Mufti A K Barkatulla, "Currency in Islamic Law: A Sharī ah analysis of bitcoin" in Fintech In Islamic Financ (Routledge, 2019) at 120-130. 
literature and legal sources of the Iranian legal system, Imamieh Jurisprudence, and EU (mainly French) Law.

After categorizing and analyzing the content, the existing concepts were materialized, and their standing in the current financial, economic, and trade legal structure of mentioned legal systems was discussed. The present research was empirical because it studied the concepts, using it to define the standing place of the cyber currency in the mentioned legal systems and how the law should treat the litigation on the cyber currency present strategies for practically improving this system. Also, comparative methods have been used to compare e-money legislation between European systems, especially France and the American system, as a typical model, and IranIslamic law as reflected in the views of jurisprudential thinkers. The comparison between Islamic-Iranian and EU law is selected because of two reasons. First, the rapidly growing crypto-currency demand in Iran is causing a great need for strong legislation in this field to help to solve the possible upcoming legal cases. Second, the EU has one of the earliest legislations in crypto-currency, and its experience is tested and can be helpful for countries lacking this legal infrastructure like Iran.

\section{THE NATURE OF CYBER CURRENCY}

Legal money or money, of which banknotes and coins are the instances, form a bank's currency. ${ }^{17}$ From the theoretical point of view, in electronic money, legal description and analysis of its nature are considered money. To prove the proposition that electronic money is money, we must first review and re-analyze the meaning and nature of each type of money and apply it to the state of electronic money. ${ }^{18}$ Before, examine the functions, economics, and duties. The legal nature of money and its characteristics is

17 Ruoke Yang, "When is Bitcoin a security under US securities law" (2013) 18 J Tech L \& Pol'y at 99.

18 Angela SM Irwin \& Caitlin Dawson, "Following the cyber money trail: global challenges when investigating ransomware attacks and how regulation can help" (2019) 22:2 Journal of Money Laundering Control. 
required as a scientific introduction. Therefore, it will follow the topics of this speech in three parts.

\section{A. Characteristics and Functions of Money}

From an economic point of view, money has at least three main functions. ${ }^{19}$ Money is an instrument or medium of exchange, a unit of calculation or measurement of value, a means of preserving and storing value. Although money today is thematically diversified and developed, there is no doubt that money's most important function and characteristic are the means of its exchange. According to some economists, only objects have this function. Widely accepted as intermediaries of exchange, they can be described as money.

As Jean Carbonier, the French jurist, pointed out: However, money is an intermediary of exchange and a means of payment; not every means of payment is money because money, in addition to fulfilling its monetary obligation, is a religion of Muscat. It also has. Therefore, any means of payment must include all the characteristics of money. ${ }^{20}$ Money is not only a means of payment; in its function as a common currency. It is a means and a tool for measuring the value and valuation of objects that have a rational benefit and economic value and are considered in the legal term of money.

In other words, currencies determine the amount of tax and price of objects. Each unit of the common currency, which is the unit of calculation and measurement, is an ideal that is necessarily defined by a name such as Rial, Euro, and Dollar and acts as a reference with society's monetary system. A set of monetary units makes up a sum of money. However, this ideal unit requires an intermediary or device to be included for storage and exchange. The instrument in which monetary units are included, sometimes in coins and sometimes in banknotes, is called a monetary

19 Mufti F Adam, "Bitcoin: shariah compliant" (2017) Amanah Finance Consultancy 2017 at $1-54$.

20 Mark Holub \& Jackie Johnson, "Bitcoin research across disciplines" (2018) 34 The Information Society at 114-126. 
document or monetary instrument in legal analysis. ${ }^{21}$ However, the common currency in any monetary system is the pure element of money, and the unit of utility used to determine the value of services and commodity needed by the people of the society is used, whether it wants to be given a material form through aggregation and inclusion in an intermediary.

\section{B. Cyber and Traditional Currencies}

To describe and analyze the nature of electronic money as money, we must first analyze the nature of money itself to apply the reality of electronic money to it. While some economists predict that money will disappear in the future by introducing new technologies, some legal experts believe that money is still an unknown quantity from a legal point of view. Although pervasive in economic relations, money is generally devoid of legal theory. The few legal definitions of money are largely based on its functions and functions as a payment unit. ${ }^{22}$ According to some French law authors, they define exchange, lawyers' view of money is principled mainly from law and obligations arising from its application. Less attention is paid to the obligations arising from its creation and publication. However, experts agree about the nature of money made from valuables such as gold and silver. Because in these cases, material and physical property with intrinsic tax and value, due to the definition of three functions for it, played the role of money and intermediary of exchange. So, logically, we should focus on the current examples of legal tender and money, namely coins and banknotes.

In the evolution of money, paper money or banknotes at the beginning of its existence expressed a claim and demand on the part of its publisher. When the convertible currency system was established, and the currencies were defined based on the number of precious metals, gold, and silver, the

${ }^{21}$ M Kabir Hassan, Mohammad S Karim \& Aishath Muneezac, "A Conventional and Sharī'ah Analysis of Bitcoin” (2020) 35:1-2 Arab Law Quarterly at 155-189.

22 Evan L Greebel, et al., "Recent key Bitcoin and virtual currency regulatory and law enforcement developments" (2015) 16:1 Journal of Investment Compliance. 
banknote issuer bank backed and issued banknotes. It was based on the gold and silver it had stored and had to exchange it for gold or its equivalent at the holder's request. ${ }^{23}$ For example, according to Article 17 of the Law of 22 April 1806, banknotes were normally payable to the holder in French law. The person receiving the bonds appointed the issuing bank as the debtor rather than the debtor. He counted the bills he had delivered to him. The banknote was considered a debt document of the issuer or a document of the holder. It could be transferred by receipt and contract. In this system, the banknote represented a transferable personal financial or religious right.

Hence, the legal nature of this type of banknote was similar to a promissory note. It represented a religious right or a transferable claim in favor of the holder, except that the restrictions and formal conditions of the promissory note were removed and its economic function and legal effect. It was completely different in exchanges. ${ }^{24}$ These banknotes had the effect of cash payment, while the promissory note is a non-cash payment instrument. The situation was similar in other European-American monetary systems with similar financial banking systems. Thus, money with backing or convertible money was, by nature, debt and a payable obligation of the issuer and a religious right or claim of the holder. The monetary document representing it, namely banknotes and coins, indicated that religion and demand. In other words, this type of banknote or coin was not property per se but indicated property, and what was taxed and considered property was the same holder of the banknote from the issuing bank. Because private banks also issued banknotes during the period in some countries, such as the United States, the exchange value of such banknotes depended on the publisher's credit and the public's confidence in the publisher's financial ability. ${ }^{25}$

23 Wulf A Kaal, "Decentralization-Past, Present, and Future" (2019) 19-23 U of St Thomas (Minnesota) Legal Studies Research Paper.

${ }^{24}$ Abbas Mirakhor, Iqbal Zamir \& Seyed K Sadr, Handbook of Ethics of Islamic Economics and Finance (Walter de Gruyter GmbH \& Co KG, 2020).

25 In the United States, since 1933, coins and banknotes issued by the Federal Reserve are the only legal forms of polling in that country that derive their value from law and public trust. 
Based on this analysis, the French Supreme Court, in its judgment of 7 April 1856, held that the tax on banknotes of the Bank of France was based on pure trust. Leaving aside the support of gold and silver and the tendency of monetary systems to convert non-convertible currencies, the legal nature of money changed completely. In French banking law, this system was implemented following the law of 1 October 1936, and according to it, the Bank of France was released from the obligation to repay issued banknotes or coins. A change has occurred in other countries, such as the United States. ${ }^{26}$ As a result, unlike in the past, the current banknote is neither a payable obligation nor a religious right of the holder. Banknotes do not indicate property but are themselves property, money whose value and tax are credit and derive from the law. In other words, the value of money is determined by the law and is taxed by law. Therefore, in many national laws, the acceptance of common currency by the general public and legal persons is mandatory. ${ }^{27}$ For example, under Article 5 of the French Law of 4 August 1993, the Bank of France is the only authorized issuer of banknotes accepted as legal tender. Any person who owes money for transactions can fulfill his debt by paying an amount equal to the amount owed to his creditor, and the creditor is required to accept those bills (currency) as a means of payment.

Legal currency is the consequence of the irreversible currency system. As soon as the legislators decide that the banknotes are irrevocable, the holders of the banknotes will be backed up. This legal guarantee must be provided, and the depositors can provide the money. Goods and services should be rejected and refused. On the other hand, the trading party will also accept the monetary symbol based on its face value (the number mentioned on the sheet).To be sure, if she/he is sure this monetary symbol is accepted at the same value. Thus, in a non-exchangeable legal monetary system, monetary symbols, both banknotes and coins, have their exchange power from the law and government support and public trust and acceptance as a valuable

${ }^{26}$ John O McGinnis \& Kyle Roche, "Bitcoin: Order without law in the digital age" (2019) 94 Ind LJ at 1497.

27 Pietro Ortolani, "Self-enforcing online dispute resolution: lessons from bitcoin" (2016) 36:3 Oxford Journal of Legal Studies at 595-629. 
object. ${ }^{28}$ People accept common currency in exchanging goods and services simply because they trust that the acceptance of that money will continue in exchange and serve as a store of lasting value. Central banks are also responsible for maintaining their integrity and originality (original exchange value) by controlling the money in circulation.

\section{The Nature of Money in Islamic Legal Thought}

Among the thinkers of Islamic law, Martyr Sadraz is one of the pioneers in analyzing the nature of money. ${ }^{29}$ After emphasizing the intrinsic value of gold and silver coins, he has made a serious distinction between banknotes that can be converted into gold and silver and current banknotes, which according to the law of publishers, are exempt from converting them into gold. Regarding the second type, like the current banknotes, which have no gold backing, and the issuer has no obligation to convert them into gold and precious metals. It is believed that these are mandatory cash bonds, and their taxation is purely credit and has no intrinsic value and price. Law and government are enacted. However, members of a society accept these securities as the price of the transaction, and the transaction takes place. Experts in Islamic law agree on the validity of the current currency (whether coins or banknotes) but differ in the quality of their value and tax. The current views can be divided into two groups and in general.

\section{Purchasing Power Theory}

The creator of this theory is Shahid Sadr, who considers the current money as a proverb whose proximity is not in the paper of banknotes and the number of units written on it, ${ }^{30}$ but as the proverb of money embodies the

${ }^{28}$ Ginevra Peruginelli \& Sebastiano Faro, "Research Quality Evaluation: The Case of Legal Studies" in The Evaluation of Research in Social Sciences and Humanities (2018) at $103-129$.

29 Dodik Siswantoro, Rangga Handika \& Aria F Mita, "The requirements of cryptocurrency for money, an Islamic view" (2020) 6:1 Heliyon.

30 Abulfathi I S Al-hussaini, et al., "Factors Influencing Adoption of Cryptocurrencybased Transaction from an Islamic Perspective" (2020) 20:4 Global Journal of Computer Science and Technology. 
real price, and the real value of money is its purchase power. Some other scholars have expressed the same theory with different interpretations. For example, a banknote is something that a reputable authority has given tax credit and value, i.e., the legislator, in purchasing power. ${ }^{31}$ In other words, the whole universe is money in exchange value and purchasing power. Therefore, in monetary debt repayment, something of the same name is not considered a repayable alternative. The match is only equal to the same concept in terms of price, value, and tax.

According to some civil rights scholars, banknotes, which are so popularly referred to as money, are not money but represent a certain amount of money and credit value. The truth of money is its exchange and credit value, and in monetary obligations, the same amount is owed to the person. If a person ten years ago was obliged to pay one million rials to another, today she/he must pay that amount to the creditor that the tax was equivalent to one million rials ten years ago. It is equal in terms of exchange value.

\section{E. Nominal Value Theory}

According to this view, credit money is no different in terms of money and the value of exchanges with real money. It exempts in terms of non-money, like consumption value. While the purchasing power is monetary, sometimes their value and purchasing power decrease in coins and silver. We must also believe in reparation, while none of the jurists has issued that fatwa. ${ }^{32}$ Therefore, the nature of money depends not on its purchasing power but the principle of exchange value and not its value, and the principle of exchange value is also a relative feature of money. In addition, if the purchasing power is the same as its actual exchange price, then financial money is not the same and should be considered a price commodity. In contrast, the jurists do not consider it a price commodity.

In summarizing and comparing the above two theories, it should be said: Although each of them has some aspects of the reality of Rabian money,

31 Siswantoro, Handika \& Mita, supra note 29.

32 Adam, supra note 1 at 133-147. 
each of them has some objections. ${ }^{33}$ The most important flaws of the theory of purchasing power are the confusion between the concepts of property and taxation and the confusion between the nature of money and the nature of religion and monetary commitment.

In addition, the acceptance of the theory of purchasing power has legal implications and implications that the proponents of the theory themselves will not be bound. The theory of purchasing power has no jurisprudential or legal evidence for its claim, and the legal texts imply otherwise. In relations between the creditor and the debtor, especially concerning monetary obligations, as stated in Article 1895 of the French Civil Code and Article 650 of the Iranian Civil Code, the repayment of the agreed amount in monetary units is the subject of the debt, and the payment of this amount owes the debtor Makes berry. ${ }^{34}$ Many contemporary jurists also believe that the monetary obligation to pay the same amount (the same amount of banknotes) leads to the acquittal of liability. The decrease or increase in the purchasing power of money does not affect this ruling.

In relations between issuers (central banks) and banknote holders, reducing purchasing power does not create civil liability for the issuer. The responsibility of governments is only political responsibility and accountability to parliament for overseeing affairs, and states guarantee the legal value of legal money and money. They are not purchasing power and, on the contrary, international regulations specify the non-responsibility of states for the devaluation and purchasing power of the national currency. ${ }^{35}$ Regardless of theoretical issues, contemporary jurists have used the traditional concept of money as a criterion by standardizing customs in

33 Nashirah Abu Bakar, Sofian Rosbi \& Kiyozaki Uzaki, "Cryptocurrency Framework Diagnostics from Islamic Finance Perspective: A New Insight of Bitcoin System Transaction" (2017) 4:1 International Journal of Management Science and Business Administration at 19-28.

34 Breu, supra note 8.

35 As a change in the value of a currency is not a breach of international law, a state is not liable for its consequences on holders of its currency or on creditors or debtors to obligations denominated in that currency. 
explaining and recognizing issues. ${ }^{36}$ Although the price of other things is measured in money, the money itself is a parable, and the guarantee is a parable. The price of a banknote does not fall short of what is set for it. A thousand dollar bill is never nine hundred dollars and is always the same as a thousand dollars without decreasing purchasing power. ${ }^{37}$

However, the difference between the currencies in any legal monetary system with banknotes or coins denoting a number or fraction of that currency is clear, and banknotes are casually referred to as money. It is not money and rather, it represents a quantity of money and credit value, and the truth of money is its exchange and credit value. Some certain facts of money have been ignored. According to this theory, the ownership of money as an object of economic value and taxation is eliminated, while money is purely taxed..$^{38}$ Acceptance of such a theory in Imami jurisprudence, which distinguishes between the concepts of wealth and tax, is not acceptable. The distinction between the concept of wealth and taxation and the duality of the two is a matter of custom.

Banknotes and coins are indeed a monetary symbol or, in our view, a monetary document representing a certain amount of money. However, the custom and wisdom of the wise considered these objects as property and gave them tax and economic value because of their exchange power. Hence, in the legal literature today, legal tender money (banknotes and coins) is considered a property of its nature. Given the custom nature of the concept of property, such a description of common currencies in different systems of money and movable property is quite acceptable considering that it has all the characteristics of movable property. In jurisprudential literature, it is almost complete or almost complete. ${ }^{39}$ They consider cash as property and

36 Paul Anning, Stuart Hoegner \& Jerry Brito, The Law of Bitcoin (Bloomington: iUniverse, 2015).

37 Adam, supra note 19.

38 Mustapha Abubakar, M Kabir Hassan \& Muhammad A Haruna, "Cryptocurrency tide and Islamic finance development: any issue?"

39 Mohd Ma'Sum Billah, Islamic Financial Products: Principles, Instruments and Structures (Palgrave Macmillan, 2019) at 413-434. 
apply all property rulings to guarantee loss and usurpation and consider them as property and not as a sign of property.

\section{CONCEPTUALIZING CYBER CURRENCY AS MONEY}

If e-money is a new form of money in the true sense of the word, it must have the basic characteristics of money, and the nature of money in the legal analysis must apply to it. Electronic money can perform a common currency's economic functions and duties and have desirable monetary characteristics such as anonymity, portability, durability, divisibility, uniformity, and uniformity. From a legal point of view, the fundamental and debatable issues regarding e-money in comparison and comparison with the legal tender are mainly two things: the ability and value of the exchanges to be used as a general means of payment and its units to be included in a monetary document. Act as common currency as a means of storing value.

\section{A. Electronic Money as a Means of Payment and Its Exchange Value}

Electronic money in its current state is the result of an exchange. In a technical and contractual process, the publisher produces an electronic mark as electronic money and in exchange for the receipt of the equivalent amount of the applicant. An electronic money issuer Unlike a legal money issuer, one does not create money but exchanges electronic signs describing electronic money with legal money at the applicant's disposal. Based on this fact, e-money publishers commit to repurchase the exchanged e-money and instead pay the equivalent to the e-money holders. Thus, electronic money is the product of agreement and is exchanged for legal money at the beginning and end of its life cycle..$^{40}$ Ensuring that the holder can convert the electronic monetary value back into banknotes increases public confidence in e-money as an effective and reliable alternative to coins and

40 Stephan Breu \& C Paterson, "Blockchains and cyber currencies challenging antitrust and competition law" (2019) Law, Ethics Society: Historical Contemporary Perspectives at 205-215. 
banknotes. However, there is no legal redemption capacity in the currency, and there is no such obligation for the issuer (central bank).

Businesses accepting electronic money receive the required electronic value of the transaction price from the consumer in exchange for the goods or services provided to the consumer ${ }^{41}$, and thus sellers based on the acquisition of electronic monetary units. The electronic or computer memory of the buyer is transmitted and registered in their system. However, concerning the buyer, it is assumed that the transaction price has been paid. Then, the electronic monetary value is considered as a means of payment. The buyer's obligation to pay the price is nullified. Because of this feature, one electron coin should be considered an alternative to legal tender (banknotes). ${ }^{42}$ Electronic money is available like a banknote and makes payment possible. Payment by electronic money does not require a connection to a bank account and funds transfer from one account to another. Like banknotes, it makes it possible to pay the price, except that the banknote's power is a valid tax due to tax credit. The means of payment is electronic money based on the agreement between the buyer and the seller and based on the publisher's commitment to repay it.

According to what we have already said in explaining the nature of legal tender, today's banknotes are movable by their very nature. They have exchanged for the transaction themselves, and by handing them over to the seller of the goods or services, the cash is exchanged, and final payment is made. Nevertheless, do the e-currencies exchanged between e-wallet holders and sellers have such a legal nature and function? If electronic currencies are considered one of the exchanges and the subject of exchange, they must be property in themselves and not be considered money.43 Assuming they are property, they are either movable property or intangible property. In the first case, we are against the assumption. Electronic monetary units cannot be classified as tangible property because they have

${ }^{41}$ Mark E Burge, "Apple pay, bitcoin, and consumers: the ABCs of future public payments law” (2015) 67 Hastings LJ at 1493.

42 Eric D Chason, "How bitcoin functions as property law" (2019) 49 Seton Hall L Rev at 129.

43 Joshua AT Fairfield, "Smart contracts, Bitcoin bots, and consumer protection" (2014) 71 Wash \& Lee L Rev Online at 35. 
no physical or physical form. Furthermore, there is no doubt that they are immaterial and intangible.

At present, when the issuers of electronic money are financial institutions and commercial banks. Electronic money has not gained the same economic and legal status as legal tender (banknotes and coins). Simultaneously, the publisher's obligation to repay it and convert it into legal tender or hard currency Electronic money and its legal requirements. Acceptance of e-money by businesses is also based on the feature that the transferee (current holder) can also demand a refund from the publisher. ${ }^{44}$ From the point of view of the Roman jurist, electronic money implies a claim or a religious or personal right. It raises the question of whether electronic money is intangible property that one owes a claim to it and is it continuously? Or is it just a claim against the publisher?

The fact is that e-money has no independent value other than the valueseeking reflected in the common amount of money. Because the publisher does not want or convert these electronic units into legal or bank currency, no trader or seller will accept them and have no exchange value. Thus, emoney issued by commercial banks and financial institutions with legal tender issued by central banks has this inherent difference: it is not considered movable in itself and taxed by the creditor. It is legal or written. Electronic money can be a means of payment, but its mechanism of action is quite different from legal money (banknotes and coins). Payment by electronic money is based on the transfer request to the seller (i.e., the transferee of one electron money) with the feature that the issuer usually does not recognize the new creditor until the creditor converts the electronic units from legal tender or currency.

However, the above analysis does not prevent money from being considered electronic money. The bottom line is that e-money is not a non-repayable or non-repayable currency like the current currency of the issuer. However, it can be a type of money that can be converted into a

${ }^{44}$ Angela SM Irwin \& Adam B Turner, "Illicit Bitcoin transactions: challenges in getting to the who, what, when and where" (2018) Journal of Money Laundering Control. 
generation of paper money that can be converted or pledged. The subcurrency of money is not convertibility or non-conversion. However, its exchangeability and acceptance are the prices of a transaction.

It should be added that today there are electronic payment schemes available to customers in anchors or e-wallets with the ability to recharge or without it by some economic enterprises that are only in non-real exchanges. ${ }^{45}$ Its services can be used. (Like telephone cards and cards of metro companies) These schemes do not provide e-money in their sense. Rather, they are merely an advance payment mechanism.

\section{B. Electronic Money as a Monetary Document}

At present, money in common units is contained in three instruments or monetary documents: coins and banknotes, and bank accounts (writing money). These three monetary instruments are of exchange value and can act as a means of storing value. Individuals usually maintain a portion of their assets, which is interpreted as a person's cash assets.

According to the analysis, e-money does not know Rapol. However, it is considered a monetary obligation, and e-money lacks the characteristic of being an instrument or a monetary document and can be considered a monetary commitment document. The distinction between the two is also clear. A monetary deed has a tangible property and the exchange value and power of fulfilling the religion. However, a monetary commitment deed is not tangible property and is considered a property reflected in that property. ${ }^{46}$ It is transferable. In other words, the delivery or transfer of a monetary commitment document can act as a means of repaying and paying in another transaction if accompanied by a transfer request. However, electronic money is not considered a kind of money in the sense of convertible money, and it is similar to previous banknotes. An electronic document containing monetary value can be interpreted as a document and

45 Alexander Kroeger \& Asani Sarkar, "The law of one bitcoin price?" (2017) Federal Reserve Bank of Philadelphia.

46 Kusuma Teddy, "Cryptocurrency for Commodity Futures Trade in Indonesia: Perspective of Islamic Law” (2020) 37:1 Journal of Islamic Banking \& Finance. 
monetary instrument because the demand is embodied and objectified in the self-document.

\section{CYBER DEPOSIT}

Banknotes and coins are not the only documents and tools for maintaining monetary units. Economists have realized over time that the assets of individuals' bank accounts are also money because they have the same legal functions. The balance of a bank account indicates the amount of money, i.e., a certain amount of monetary units (USD 1,000, for example), independent of the monetary documents that contain it (for example, twenty dollar bills). It is independent of claims that act as a means of payment and transfer in business (such as checks). ${ }^{47}$ Thus, bank money is an amount of money that is registered in a bank account. It is transferred from one account to another through a non-cash payment device, such as a check. In other words, the term bank or written money has various documents such as checks, bank cards, and credit transfers $(\mathrm{L} / \mathrm{C})$ that allow the circulation of writing money. In the legal analysis of the relationship between the depositor and the bank, the bank owns bank (current) and savings bank deposits. The bank is obliged to repay the deposit amount to the account holder(The nominal value of the deposited units). For this reason, the bank can use the funds it has received and take ownership of them.

The use of non-cash means of payment, such as a check, is the transfer of an account holder's order to pay all or part of the account balance or its transfer to the beneficiary's account. Therefore, even if the bank confirms the check, the funds are not transferred. However, only the money transfer mechanism of the issuer is withdrawn from the bank. In French jurisprudence and following Article 62 of the Czech Rules of Procedure, the issuance of a check is effected if an impossible bank pays the check and

${ }^{47}$ Jon Truby, "Decarbonizing Bitcoin: Law and policy choices for reducing the energy consumption of Blockchain technologies and digital currencies" (2018) 44 Energy research \& social science at 399-410. 
if the bank imposes the funds on another bank account. ${ }^{48}$ The bank does not transfer a claim or religious right but transfers an amount of money (i.e., units of common currency) recorded in the beneficiary's account. Bank money or writing is a form of money because it is a reserve of value (units of common currency) that can be transferred from one account to another and act as a means of payment in transactions.

\section{A. Applying the Nature of Written Money to Electronic Money}

Electronic money schemes have several significant differences from the conventional bank deposit system. First, the funds that the publisher first receives in exchange for the issuance of electronic money are not recorded to a specific bearer. Its repayment is not necessarily to a specific person. Although some legal writers do not consider this difference significant and believe that financial institutions should account for customer deposits, they do not have a duty to record it in their offices. ${ }^{49}$ An electronic money storage card is like a savings account in which the customer's account balance is recorded and is owned by the customer.

Second, if the holder uses electronic money, payment requires immediate change and reduction of their e-wallet inventory and the increase of the accepting device (seller)..$^{50}$ However, in the payment of the bank account balance (i.e., payment with written money), the payment is made by check or bank card of the buyer, the payment is made in the form of funds transfer, and the buyer's account owes the desired amount and the seller's account.

Bank accounts assume the role of a monetary document. However, unlike other monetary instruments, such as banknotes and coins, they do not cause the circulation and circulation of common units. Bono shooter points

48 Ben Van Vliet, “An alternative model of Metcalfe's Law for valuing Bitcoin” (2018) 165 Economics Letters at 70-72.

49 Spencer Wheatley, et al., "Are Bitcoin bubbles predictable? Combining a generalized Metcalfe's law and the log-periodic power law singularity model" (2019) 6:6 Royal Society open science.

50 Lawrence J Trautman, "Bitcoin, virtual currencies, and the struggle of law and regulation to keep the peace" (2018) 102 Marq L Rev at 447. 
out, unlike banknotes and coins, which are both monetary documents and coins. They are also a means of payment; writing money is just money and not a means of payment. ${ }^{51}$ Payment by written or banknotes is possible with the help of payment instruments such as checks and bank cards. These devices make the payment by accessing the account holder's bank (based on the transfer of funds to the creditor's account) through a double exchange (debiting the payer's account and settling the payer's account).

E-money is quite the opposite. Electronic money is not considered a monetary document. However, it is a means of payment, and as mentioned, this payment does not require the transfer of funds from one person's account to another. While from the buyer's point of view, final payment has been made by handing over electronic money to the seller, or more precisely, by transferring electronic units from the buyer's card to the seller's system. However, according to the publisher, no money transfer has taken place between the buyer and seller. In a single (aggregate) account, the electronic money issuer records all the monetary amounts received in exchange for the issued electronic units. Transferring electronic money from the buyer to the seller does not change the issuer's debit balance. In an e-money payment system, a transfer of money occurs when the seller (the e-money accepting firm) asks the issuer to convert the electronic units he accepted at the time of payment into legal or written money.

Although the aggregate account of the electronic money issuer acts as a store of value, the electronic units are not considered property in themselves. They merely represent the claimants' claim against the account. Therefore, they are not a new form of monetary instrument and are merely a new means of payment. Therefore, due to the significant differences between one electron coin and written money (bank deposits) and the mechanism of action of the two, it is somewhat theoretically difficult to apply the nature of written money to electronic money.

51 Matthew P Ponsford, "A comparative analysis of bitcoin and other decentralized virtual currencies: legal regulation in the People's Republic of China, Canada, and the United States" (2015) 9 HKJ Legal Stud at 29. 
In the case law, there is also a difference of opinion whether electronic money is of the nature of a deposit as subject to their regulations or a different nature. Therefore, it is considered a general obligation moneyissuing institution other than a deposit. In ECB Regulation 2001/13, the amount owed by the issuer in respect of issued electronic money is classified as deposit liabilities. However, in US federal regulations, the value stored in e-wallet smart cards is considered a general obligation, not a deposit..$^{52}$ The importance of this description lies in the fact that in addition to making the issuance of e-money by non-banking institutions possible and excluding the proceeds from the rules and requirements of bank deposits. It also determines the legal nature of some legal writers who have likened online e-money only to a debit card or a debit card in a plan that allows access to the account holder. ${ }^{53}$ Some writings have used online emoney schemes as a form of cash and not a kind of deposit.

However, if the funds that electronic money holders pay to publishers are a kind of deposit, and electronic tokens are tools that, firstly, are the reason and evidence of the funds deposited in favor of the holder and, secondly, have the means and tools to do so. Instead, the repayment of the funds deposited with the issuer to the holder has transferred the electronic monetary sign. Functional electronic signs are like checks, in which the holder can return some or all of the funds deposited with the publisher or transfer them to another. (Article 310 of the Iranian Commercial Code) Some authors believe that the electronic money bag is like a savings account..$^{54}$ When a customer wants to buy goods from a merchant, he presents the savings ledger to the merchant (as a representative and trustee), and he deducts an amount from the ledger and adds the same amount to his ledger credit.

The above analysis is acceptable to the extent that the electronic money issuer of banks and financial and credit institutions and the relevant

52 Max Kubat, "Virtual currency bitcoin in the scope of money definition and store of value" (2015) 30 Procedia Economics and Finance at 409-416.

53 Filka C Windiastuti \& Fauzul H N Athief, "Inacoin cryptocurrency analysis: an Islamic law perspective" (2019) 2:2 Journal of Islamic Economic Laws at 152-177.

54 Mohamad Roshan, Mostafa Mozafari \& Hanieh Mirzayi, "Jurisprudential and law Investigation into Bitcoins" (2019) 22:87 Journal of Law Research at 49-78. 
account is subject to the regulatory regulations of the Central Bank. Because despite the mentioned differences, it performs the functions and duties of bank money. If payment instruments, i.e., electronic signs, are significantly different from checks. First, checks are non-cash means of payment, but it is assumed that electronic money is a primary means of payment. Second, the ownership of electronic money, like a banknote, is subject to the rule, and its possession is the reason for the owner. Usually, the issuer is not responsible for its loss or theft, and the real holder of the stolen electronic money card cannot be returned to the publisher. In contrast, the loss of an ordinary check does not deprive the holder of his legal right. He can receive the amount by using the provisions related to the loss of the check (Article 14 of the Penal Code and Article 314 of the Code of Criminal Procedure). Despite the differences of opinion that exist in different legal systems about the need for clear ownership of the check and limited transfer of its ownership, ${ }^{55}$ electronic money does not need to have a material aspect, and with the transfer of electronic bits, the ownership of the money passes to the new holder.

\section{B. Non-monetary Theories in Analyzing the Nature of Electronic Money}

According to the views that give electronic money a non-monetary nature, e-money is a claim against money in its legal analysis. These claims and claims are transmitted from one intermediary to another, from one electronic instrument to another, until they are converted and repaid by the publisher into legal tender.

It may be argued that e-money is the issuer's electronic document of transferability and obligation, and the holder can use it in his exchanges as a means of fulfilling an obligation, and according to the prevailing legal system, by using the same legal establishment. Assignment of the right (demand), remittance, sale, or peace of religion, transfer it to the transaction. However, the interpretation of e-money as a simple religion

55 Navabpour Alireza, Yousefi Ahmad Ali \& Talebi Mohammad, "Jurisprudential Analysis of Cryptocurrencies' Functions-Case Study of Bitcoin” (2019) 18:72 213243 at $213-243$. 
and demand and its transfer in the traditional forms of the law of obligations is logical and true to its purpose. It makes its transfer subject to the procedures of assignment of students other than similar institutions in civil law. It also opens the door to objections and defenses related to the legal relationship between the claim contained in the electronic money and the underlying contract. In addition, such an approach deprives e-money of its legal benefits and economic functions as an instant and quasi-monetary means of payment. Therefore, any legal analysis and interpretation of this phenomenon should be made to achieve its practical goals.

\section{Analysis of Electronic Money as a Document in the Face of a Digital Carrier}

A "document in the form of a carrier" is a piece of paper or writing under which the issuer undertakes to pay a certain amount to any person who seizes and delivers it in a certain promise or upon request. The relationship of documents in the form of the carrier with commercial documents in the specific sense, general and specific, is modal. In our law, bonds and participation bonds are also examples of bearer documents.

The document has several features in terms of legal status. Article 320 of the Commercial Code of Iran outlined that the possessor of the document is the owner of the document and the holder of the right to be listed in it unless proven otherwise. The current document, such as commercial documents, is itself a representative and the reason for employment is the signatory. The holder does not need any other reason to prove his claim. Except in cases where the competent judicial authority or the police prohibit the payment of that document, the payment to the bearer shall release the debtor. In case of loss of the document, the creditor and the real holder of the document can demand his claim from the debtor through the legal formalities (Articles 322 to 333 of the Iranian Commercial Code). Except in the case of a decree invalidating a document issued by a competent court, the debtor shall not be obliged to pay the document in the name of the bearer, except in return for obtaining a document or a court order to deposit the same amount in the box of justice (Article 331 of Iranian Commercial Code). Documents as portable have the description of 
transferability. Their transfer to third parties is without formalities. It enables the holder to transfer it to another with a receipt and contract in a simple process and following the provisions of the Commercial Code. In addition to what is specified in the relevant regulations regarding commercial documents on the bearer's side. In some systems, the judicial procedure has applied the principle of not paying attention to the objections against the holder in good faith regarding all the documents on the bearer's side. ${ }^{56}$ Due to this principle, the publishers cannot present the objections and defenses related to his relationship with the original holder of the document to the successive holders because they have promised to pay it to each holder. With the lack of endorsement of the document and its transfer by receipt and contract, the transferor of the document has limits. It has neither obligation nor responsibility in case of non-payment of the document nor debts and bankruptcy of the document's issuer. Otherwise, he has secured the back of the document as a guarantor.

However, in most national systems and international regulations, the positive value of message data is accepted. Whenever there is a text required by law, the message data is written in the sentence. Some legal analysts believe that something is more than a simple request and should be classified as a document in the carrier's face because electronic units represent all the documents in the carrier's face that are inserted in an electronic medium and have the effect of completing the transaction. According to this view, e-money, in addition to having the characteristics mentioned in the documents, has the power to act and, by transferring it to the next person, causes the debt of the transferor of the electronic money to be paid to the transferee.

Regarding the relationship between the electronic money holder and the publisher, its analysis as a document in the carrier's face can be rooted in the contract between the publisher and the first holder. Electronic money is an anonymous document in which the creditor's name is not mentioned in this analysis. The publisher, as the debtor, undertakes to pay the amount to

56 Mohammad Mahdi Soleymanipour, Hamed Sultaninejad \& Pourmotahar Mahdi, "Jurisprudential Investigation into Virtual Money" (2017) 6:2 Islamic Finance Research Bi-quarterly Journal. At 167-192. 
the holder of the document upon request. Such an obligation as a general holder is described as an obligation in favor of a third party in the original contract. Contracts will largely determine the rules and regulations governing this new anonymous document concluded between the issuer and the holder, the issuer and the commercial accepting companies, the issuer and the intermediary banks, and the clearing and settlement institutions. ${ }^{57}$ This digital document is not subject to the specific provisions of the Commercial Code and is not governed by the provisions of bill, promissory note, and check. However, the question arises as to whether the mere submission of the e-money and its transfer to the functional seller acts as a cash price and is considered a final payment. ${ }^{58}$ If the answer is yes, how is this process legally analyzed and according to the description of electronic money as a document in the carrier's status, and under what conditions does it break the buyer's obligation to pay the price?

Some French legal writers believe that payment by depositing a claim does not invalidate the debtor's debt. For this type of payment to achieve the full and final performance of the obligation, the creditor must agree that the first claimant must be considered fulfilled. This follows from the provisions of Article 1275 of the French Civil Code, which states: In the representation and assignment by which the obligor introduces another obligor as the obligor and obliges the latter obligee against the obligor, the obligation does not become the obligation. It explicitly states that Ebra, the obligor who made this transfer, intended. Thus, the fall of the buyer's obligation to the seller is subject to the declaration of the seller's will and intention in this regard. ${ }^{59}$ Doubt in this regard is how the seller must express his intention to inform the buyer. Some commentators on French civil law believe that this intention should be explicitly stated and implicit.

Other commentators believe that there is no valid reason for such a condition and that the implicit intention must be considered sufficient,

57 Ibid at 167-192.

58 Reza Mirzakhani \& Hosein Ali Sa'adi, "Bitcoin and the Financial-Legal Nature of Digital Money” (2018) 15:30 Journal of Iran’s Economic Essays at 71-92.

59 Ibid. 
provided it is definite and certain. ${ }^{60}$ If the agreements concluded between the issuer and the e-money accepting firms include conditions for the full and final fulfillment of the buyer's obligation, it can be a sufficient reason for the e-money acceptor's intention to issue it.

According to the rules of Iranian law, this payment process does not require the completion of the formalities mentioned above, and the holder of the electronic money can make the request reflected in it (which is considered the publisher's religion) in exchange for receiving goods or services in the form of a contract of sale or peace. Or exchange service provider. Given that the buyer's claim for the entire property is the responsibility of the issuer, the said exchange is subject to the buyer being the same or as a buyer, and if it is generally the responsibility of the seller, with the suspicion of invalidity of the sale of the goods to the whole. There will be an Imam in jurisprudence. However, some scholars consider the sale of goods invalid if it requires the exchange of religion for religion. Therefore, the analysis of the nature of electronic money in the form of a document in the form of a carrier with the characteristics mentioned above, features, and limitations, despite its relative desirability, makes the function of electronic money as a means of cash payment difficult in at least some cases.

\section{Analysis of Electronic Money as a Traveler's Check}

Electronic money is not a payment method associated with the holder's bank account and therefore is not a non-cash means of payment like a check. Its owners generally do not have an account with the publisher. From the point of view of some researchers, the payment system is different from banknotes and different from bank accounts and traveler's checks because the method of issuance and its function is the same as a traveler's check. An amount of money is given to the issuer and issuer, which is the bank and the credit institution, in exchange for which a document and a tool are issued and placed at the disposal of the holder,

60 Asghar Mahmoudi, "A Comparative Analysis of Crypto-Currencies in the Light of Jurisprudence and Law" (2019) 49:3 Law Quarterly at 503-522. 
which can be used to pay for goods and services obtained from commercial enterprises.

Accordingly, e-money has the same function and nature as a traveler's check, which gives the holder the means to pay for the goods or services required and the issuer an obligation to repay the amount defined in it to anyone who submits the card. ${ }^{61}$ In addition, a traveler's check generally contains a receipt based on which it can be freely circulated and transferred without the need for formal formalities. Some authors distinguish between different electronic money schemes and consider its offline type as a traveler's check and its online type as a debit or debit card. In analyzing the legal nature of traveler's checks, this is a positive payment instrument, embodied and crystallized in the document. It is called check and quasimoney. In the case of e-money analysis as a traveler's check, its issuance and circulation in many legal systems will face the relevant legal restrictions.

\section{E. Analysis of Electronic Money as the Nature of Special Rights}

Unlike a traveler check, e-money is an anonymous document contained in a microchip and not a paper medium. Thus, e-money is inherently transferable securities, and, like other anonymous securities, its tax is embodied and documented in the document or the sign. Nevertheless, some authors believe that electronic money is an electronic document that has its nature and also exists. The immaterialization of a pre-existing paper document (such as a traveler check) is not. ${ }^{62}$ However, this view does not provide a clear analysis of the specific legal nature of the application. Contrary to the above view, it is sometimes said that electronic money does not have a special legal nature. Its electronic component only provides a way to record information and send messages ${ }^{63}$ From this point of view,

${ }^{61}$ Soleymanipour, Sultaninejad \& Mahdi, supra note 56 at 167-192.

${ }^{62}$ Morteza Chitsazian \& Zahra Khorsandi, "Digital Currencies from the Perspective of Jurisprudence and Law" (2021) 8:3 International Journal of Multicultural and Multireligious Understanding. At 88-96.

63 Al-hussaini et al, supra note 30. 
electronic money is not a new nature that requires the invention of new legal rules and easily fits into existing legal frameworks.

\section{CONCLUSION}

Electronic money emerges different from electronic methods of transferring funds. In analyzing the legal nature of this phenomenon, two different approaches can be adopted. The first approach is to analyze the nature of electronic money as a kind of money. Based on the views presented on the nature of money presented and reviewed in this study, describing the nature of electronic money as a type of money does not seem so difficult.

Given the literature and theories in this field, two main approaches have been classified. The first one is monetary theories which consider e-money as something with the natural value same as the traditional value money has, and it can be considered under current financial and monetary legislation. However, the second approach considers the non-monetary theories and states that the traditional monetary legislation cannot be applied to many legal cases related to e-money transactions. It suggests that a hybrid financial market competitive monetary legislation must be established for e-money cases. Therefore, the second approach is the most effective, and e-money needs to be considered a separate monetary system with unique legislation.

\section{ACKNOWLEDGMENTS}

None.

\section{REFERENCES}

Abubakar, Mustapha, M Kabir Hassan \& Muhammad A Haruna, "Cryptocurrency tide and Islamic finance development: any issue?"

Adam, Faraz, "Fatawa Analysis of Bitcoin" in Halal Cryptocurrency Management (Palgrave Macmillan, 2019). 
Adam, Mufti Faraz \& Mufti A K Barkatulla, "Currency in Islamic Law: A Sharì' ah analysis of bitcoin" in Fintech In Islamic Financ (Routledge, 2019).

Adam, Mufti F, "Bitcoin: shariah compliant" (2017) Amanah Finance Consultancy 2017.

Al-hussaini, Abulfathi I S, et al., "Factors Influencing Adoption of Cryptocurrency-based Transaction from an Islamic Perspective" (2020) 20:4 Global Journal of Computer Science and Technology.

Alireza, Navabpour, Yousefi Ahmad Ali \& Talebi Mohammad, "Jurisprudential Analysis of Cryptocurrencies' Functions-Case Study of Bitcoin” (2019) 18:72 213-243.

Anning, Paul, Stuart Hoegner \& Jerry Brito, The Law of Bitcoin (Bloomington: iUniverse, 2015).

Bakar, Nashirah Abu, Sofian Rosbi \& Kiyozaki Uzaki, "Cryptocurrency Framework Diagnostics from Islamic Finance Perspective: A New Insight of Bitcoin System Transaction" (2017) 4:1 International Journal of Management Science and Business Administration.

Begusic, Stjepan, et al., "Scaling properties of extreme price fluctuations in Bitcoin markets" (2018) 510 Physica A: Statistical Mechanics and its Applications.

Billah, Mohd Ma'Sum, Islamic Financial Products: Principles, Instruments and Structures (Palgrave Macmillan, 2019).

Breu, Stephan, "Are Blockchains and Cybercurrencies Demanding a New Legislative Framework” (2018) 1 Journal Law and Digital Economy.

Breu, Stephan \& C Paterson, "Blockchains and cyber currencies challenging antitrust and competition law" (2019) Law, Ethics Society: Historical Contemporary Perspectives.

Burge, Mark E, "Apple pay, bitcoin, and consumers: the ABCs of future public payments law" (2015) 67 Hastings LJ.

Chason, Eric D, "How bitcoin functions as property law" (2019) 49 Seton Hall L Rev. 
Chitsazian, Morteza \& Zahra Khorsandi, "Digital Currencies from the Perspective of Jurisprudence and Law" (2021) 8:3 International Journal of Multicultural and Multireligious Understanding.

Fairfield, Joshua AT, "Smart contracts, Bitcoin bots, and consumer protection" (2014) 71 Wash \& Lee L Rev Online.

Farrukh, Habib, "Fintech, Digital Currency and the Future of Islamic Finance" in A Critical Analysis of Bitcoin from Islamic Legal Perspective (Palgrave Macmillan, 2021).

Greebel, Evan L et al, "Recent key Bitcoin and virtual currency regulatory and law enforcement developments" (2015) 16:1 Journal of Investment Compliance.

Hassan, M Kabir, Mohammad S Karim \& Aishath Muneezac, "A Conventional and Sharī'ah Analysis of Bitcoin” (2020) 35:1-2 Arab Law Quarterly.

Holub, Mark \& Jackie Johnson, "Bitcoin research across disciplines” (2018) 34 The Information Society.

Irwin, Angela SM \& Caitlin Dawson, "Following the cyber money trail: global challenges when investigating ransomware attacks and how regulation can help" (2019) 22:2 Journal of Money Laundering Control.

Irwin, Angela SM \& Adam B Turner, "Illicit Bitcoin transactions: challenges in getting to the who, what, when and where" (2018) Journal of Money Laundering Control.

Kaal, Wulf A, "Decentralization-Past, Present, and Future" (2019) 19-23 U of St Thomas (Minnesota) Legal Studies Research Paper.

Kroeger, Alexander \& Asani Sarkar, "The Law of One Bitcoin Price?" (2017) Federal Reserve Bank of Philadelphia.

Kubat, Max, "Virtual currency bitcoin in the scope of money definition and store of value" (2015) 30 Procedia Economics and Finance.

Mahmoudi, Asghar, "A Comparative Analysis of Crypto-currencies in the Light of Jurisprudence and Law” (2019) 49:3 Law Quarterly. 
Manimuthu, A, et al., "A Literature Review on Bitcoin: Transformation of Crypto Currency Into a Global Phenomenon" (2019) IEEE Engineering Management Review.

McGinnis, John O \& Kyle Roche, "Bitcoin: Order without law in the digital age" (2019) 94 Ind LJ.

Mengjia, Y. U. "Analysis of Impact and Nature of Cyber Virtual Currency Based QB." (2014) Business Economy.

Mirakhor, Abbas, Iqbal Zamir \& Seyed K Sadr, Handbook of Ethics of Islamic Economics and Finance (Walter de Gruyter GmbH \& Co KG, 2020).

Mirzakhani, Reza \& Hosein Ali Sa'adi, "Bitcoin and the Financial-Legal Nature of Digital Money” (2018) 15:30 Journal of Iran's Economic Essays.

Nafis, Alam, Lokesh Gupta \& Zameni Abdolhossein, "Cryptocurrency and Islamic Finance" in Fintech and Islamic Finance (Palgrave Macmillan, 2019).

Nurhisam, Luqman, "Bitcoin: Islamic law perspective” (2017) 5:2 Qudus International Journal of Islamic Studies.

Ortolani, Pietro, "Self-enforcing online dispute resolution: lessons from bitcoin" (2016) 36:3 Oxford Journal of Legal Studies.

Peruginelli, Ginevra \& Sebastiano Faro, "Research Quality Evaluation: The Case of Legal Studies" in The Evaluation of Research in Social Sciences and Humanities (2018).

Ponsford, Matthew P, "A comparative analysis of bitcoin and other decentralized virtual currencies: legal regulation in the People's Republic of China, Canada, and the United States" (2015) 9 HKJ Legal Stud.

Roshan, Mohamad, Mostafa Mozafari \& Hanieh Mirzayi, "Jurisprudential and law Investigation into Bitcoins" (2019) 22:87 Journal of Law Research.

Siswantoro, Dodik, Rangga Handika \& Aria F Mita, "The requirements of cryptocurrency for money, an Islamic view” (2020) 6:1 Heliyon. 
Soleymanipour, Mohammad Mahdi, Hamed Sultaninejad \& Pourmotahar Mahdi, "Jurisprudential Investigation into Virtual Money" (2017) 6:2 Islamic Finance Research Bi-quarterly Journal.

Teddy, Kusuma, "Cryptocurrency for Commodity Futures Trade in Indonesia: Perspective of Islamic Law" (2020) 37:1 Journal of Islamic Banking \& Finance.

Trautman, Lawrence J, "Bitcoin, virtual currencies, and the struggle of law and regulation to keep the peace" (2018) 102 Marq L Rev.

Truby, Jon, "Decarbonizing Bitcoin: Law and policy choices for reducing the energy consumption of Blockchain technologies and digital currencies" (2018) 44 Energy research \& social science.

Van Vliet, Ben, "An alternative model of Metcalfe's Law for valuing Bitcoin” (2018) 165 Economics Letters.

Wheatley, Spencer et al, "Are Bitcoin bubbles predictable? Combining a generalized Metcalfe's law and the log-periodic power law singularity model" (2019) 6:6 Royal Society open science.

Windiastuti, Filka C \& Fauzul H N Athief, "Inacoin cryptocurrency analysis: an Islamic law perspective" (2019) 2:2 Journal of Islamic Economic Laws.

Yang, Ruoke, "When is Bitcoin a security under US securities law" (2013) $18 \mathrm{~J}$ Tech L \& Poly.

Zharova, Anna \& Ian Lloyd, "An examination of the experience of cryptocurrency use in Russia. In search of better practice" (2018) 34:6 Computer Law \& Security Review 1300-1313. 